\title{
ORIGINAL PAPER \\ The links between gold, oil prices and Islamic stock markets in a regime switching environment
}

\author{
Walid Chkili ${ }^{1,2}$
}

Received: 9 July 2021 / Revised: 15 October 2021 / Accepted: 6 January 2022 /

Published online: 9 February 2022

(C) The Author(s) under exclusive licence to Eurasia Business and Economics Society 2022

\begin{abstract}
This paper investigates the linkages between gold, oil prices and Islamic stock market for the turbulent period 1996-2020 which covers the recent COVID-19 pandemic crisis. The paper applies standard VAR and Markov switching VAR models. Empirical results can be summarized as follows: (i) There are some significant relationships between the considered markets. (ii) The sign of the links varies significantly according to markets and regimes. (iii) There is a significant and positive link between oil and Islamic stock markets namely during turbulent periods suggesting the financialization of the crude oil market. (iv) The negative or the absence of relationships between gold market and both oil and Islamic stock markets indicate that gold can act as a hedge and safe haven during extreme market conditions. These findings have several practical implications for risk-management and portfolio diversification strategies.
\end{abstract}

Keywords Oil prices · Gold · Islamic stock market · Markov switching · Financialization $\cdot$ Safe haven $\cdot$ COVID-19

JEL classification $\mathrm{C} 32 \cdot \mathrm{F} 30 \cdot \mathrm{G} 15$

This article is based upon the 26th Economic Research Forum (ERF) conference paper which is presented at the webinar session on September 16th, 2020, and which was published as ERF proceedings ( ${ }^{\circ}$ : ERF26_216).

Walid Chkili

walidchkili@yahoo.fr

1 Faculty of Economics and Management of Nabeul, University of Carthage, Nabeul, Tunisia

2 Faculty of Economics and Management of Tunis, International Finance Group Tunisia Lab, University of Tunis El Manar, Tunis, Tunisia 


\section{Introduction}

The relationship between stock and commodity markets has been extensively examined during the last two decades. Even more, most of research has focused on the links between conventional stock markets and crude oil and gold prices. This interest has swiftly grown in recent years with the instability of the oil and financial markets owing to the emergence of several political and economic events. Therefore, understanding the linkages between these markets and specifying their evolution over time can provide important implications for international investors, risk-managers and policy makers.

Large number of studies has been carried to uncover the connectedness between oil and stock markets. In this vein, various econometric models have been applied in order to test the volatility spillover between the two markets and to derive the diversification opportunities between them (see inter alia Filis et al., 2011; Chkili et al., 2014; Boubaker \& Raza, 2017; Mokni \& Youssef, 2019; Sakaki, 2019; GomezGonzalez et al, 2021). ${ }^{1}$ In addition, some researches try to check the validity of the oil market financialization hypothesis. They find that fluctuations of stock returns can impact oil returns suggesting the financialization process of crude oil market (Creti et al., 2013; Gomez-Gonzalez et al, 2021; Kolodziej et al., 2014; Olson et al., 2014; Zhang et al., 2017).

The issue of the role of gold as a hedge and safe haven for stock market goes back to the seminal paper of Baur \& Lucey (2010). According to the authors, an asset is regarded as a hedge during a given period if it is negatively correlated or uncorrelated with another asset on average. While, an asset is considered as a safe haven if it is negatively correlated or uncorrelated with another asset in times of extreme markets movements. Afterwards, several studies have been developed to investigate the sort of relationship between gold and various financial markets including stock, foreign exchange and bond markets (see eg. Baur \& McDernott, 2010; Coudert \& Raymond-Feingold, 2011; Ciner et al, 2013; Reboredo, 2013a; Chkili, 2016; Wen \& Cheng, 2018; Izadi \& Hassan, 2018; Vardar et al, 2018; Shahzad et al., 2020; Uddin et al., 2020). More precisely, these researches attempt to check the role that can play the gold as a hedge and safe haven for these markets and to uncover any beneficial diversification opportunity between them. Uddin et al. (2020) examine the risk spillover between US stock market and precious metals and oil. Using the copula approach, they find weakly spillover effect from gold to US stock market indicating that international investors can use this precious metal as an equity portfolio diversifier. Shahzad et al. (2020) reveal that gold can be regarded as indisputable safe haven and hedge for several G7 stock indices. Roboredo (2013a) tests the ability of gold as hedge and safe haven for USD exchange rate variations. Empirical results point out on the one hand that gold can serve as a hedge against USD rate movements. On the other hand, gold can be considered as an effective safe haven against extreme USD rate downturn.

\footnotetext{
${ }^{1}$ For a detailed literature review on the links between oil price and stock market, see Lang \& Auer (2019).
} 
Recently, this topic is extended to the nexus between gold and other commodity prices, with special attention is paid to crude oil market. In this vein, Roboredo (2013b), Chkili (2015), Tiwari and Sahadudheen (2015), Salisu et al. (2020), Salisu and Adediran (2020), Saadaoui et al. (2020) and Adekoya et al. (2020) among others examine the hedge and safe haven potential of gold against oil price fluctuations. Roboredo (2013b) suggests that gold exhibits safe haven qualities against oil price movements. Salisu et al. (2020) assess the possibility of using gold as hedge and safe haven against oil price risks using the asymmetric VARMA-GARCH model. They conclude that gold can act as a significant safe haven against oil price fluctuations namely during the COVID-19 outbreak.

It is worth noting that a great interest has been addressed during the few recent years towards the Islamic finance area. This interest is due to the risk-hedging alternatives and investment opportunities offered by the Islamic financial markets to portfolio managers, financial analysts and investors. Thereby, the Islamic capital markets have grown rapidly, achieving a growth rate between 19 and $23 \%$ at the end of 2017 (IFSI, 2018). ${ }^{2}$ The reasons for this fast growing are the strong investment in the halal sectors and the raise in demand for products complying with the principles of the Islamic law (or Sharia). ${ }^{3}$ In addition, the competitive nature for some of these products has attracted both Muslim and no Muslim investors. Given the importance granted to these markets, it is interesting to analyze the extent of information transmission between these markets and other asset classes such as gold and crude oil as well as the potential diversification benefits between them.

This paper contributes to the existing literature in three ways. Firstly, this paper investigates the relationship between Islamic stock market and two major commodities namely crude oil and gold. The main objective is to verify on the one hand the financialization process of the crude oil market through the analysis of the correlation between the oil and Islamic equity index. On the other hand, to test the role of gold as a hedge and safe haven against the oil and Islamic stock market movements. Secondly, the period under investigation covers several economic and political events namely the Asian financial crisis, the dot-com bubble, the global financial crisis and the COVID-19 pandemic. Such events can affect the market dynamics and so the extent of connectedness between the three variables. Given these circumstances, we fill the vacuum in the topic by analyzing the nexus between the three markets for both bear and bull market conditions. Thirdly, we apply the Markov switching VAR (MS-VAR) approach which allows us to test the relationship between the three assets for both normal and turbulent periods. This study is becoming increasingly important after the current outbreak of COVID-19. The pandemic is emerged in China and has swiftly spread globally. In addition, its effects have been quickly reverberated on the financial and commodity markets. Therefore, this survey can help Islamic investors to opt for the optimal diversification strategies and to choose the better hedging tools namely for period characterized by the alternation between normal and turbulent phases.

\footnotetext{
2 Islamic Financial Service Industry: stability report 2018: www.ifsb.org

3 See Chkili (2017), Hammoudeh et al. (2014).
} 
The remainder of the paper is organized as follow. Section 2 displays a short literature on the nexus between Islamic stock market and commodity prices. Section 3 describes the methodology. Section 4 presents the data and preliminary analysis. The empirical results are reported in Sect. 5. Section 6 concludes the paper.

\section{Literature review}

The literature that examines the relationship between Islamic stock market and commodity market is rare. Nagayev et al. (2016) investigate the dynamic relationship between commodities and Islamic market and the potential diversification opportunity between the two assets. The authors apply the MGARCH-DCC and Wavelet Coherence analysis for data ranging from January 1999 to April 2015. Their empirical evidence shows that the correlations between the two markets are time varying and high volatile during the period study suggesting that not all commodities always offer equally good diversifiers. According to the authors, gold, natural gas, agriculture, grains and livestock provide a good diversification opportunity for short-term investors for the pre-global financial crisis period. Therefore, natural gas represents the best diversifier in the short run during and after the crisis. Khan et al. (2015) find that the correlation between commodity and Islamic stock markets varies considerably over time. Moreover, the Global financial crisis has played a key role on the dynamic linkage between the two markets and highlighting the financialization of commodity markets.

Shahzad et al. (2018) examine the extreme dependence between the major Islamic equity market and oil price using copula approach. The findings show evidence of asymmetric risk spillover from oil to Islamic equity market and vice versa. More interestingly, this asymmetric risk spillover is greater after the 2008 global financial crisis.

Chebbi and Derbali (2016) use the DCC-GARCH approach to explore the evolution of the causality and dynamic correlation between commodity and Islamic stock returns over time. They conclude that the volatilities of the two markets are significantly correlated and the correlation is time-varying and highly volatile. Quite similar results are detected by Chebbi and Derbali (2015). They find significant correlation between commodity prices and the QE Al Rayan Islamic index and that this correlation follows a time-varying dynamic process.

Maghyereh et al. (2019) study the dynamic interdependence between gold, Sukuk and Islamic equities for the period September 2005-February 2018. ${ }^{4}$ The paper also highlights the diversification opportunity between the three assets. Empirical findings suggest that gold continues to play its traditional role as a hedge for Islamic equity market across all investment horizons. More precisely, gold is a good diversifier for Islamic equity portfolio in the short run. In addition, investors should allocate $30 \%$ of their wealth in gold market in order to reduce the risk of an Islamic stock portfolio regardless

\footnotetext{
4 Some papers study the links between Islamic bonds or Sukuk and commodity market (see e.g. Naifar, 2018; Metadjer \& Boulila, 2018).
} 
of the time horizon. In the same context, Chkili (2017) examines the role of gold as a hedge and/or safe haven for Islamic stock market volatility. Using Markov switching model, results reveal that gold can serve as a hedge and safe haven for extreme Islamic market conditions.

Tuna (2019) analyzes the presence of a significant link between four precious metals namely gold, silver, platinum and palladium, and 32 Islamic stock markets belonging to emerging and developed countries. He reveals, on the one hand that all the four precious metals are effective portfolio diversification instruments for developed Islamic markets. On the other hand, only gold and palladium provide an effective opportunity of diversification for developing countries. Sakti et al. (2018) find that gold offers good diversification benefits for short-term Islamic equity investments. Naeem et al. (2021) explore the relationship between the returns of gold, Dow Jones World Islamic index and ten Islamic sectoral indices. Using the quantile-on-quantile regression, they conclude that gold serves as a diversifier for the global Islamic equity index and most of the Islamic stock sectors during normal periods. In the same vein, Alkhazali and Zoubi (2020) emphasize that investors can accomplish the appropriate investments by using gold to diversify their Islamic stock portfolios.

The oil price uncertainty observed during the crisis periods has increasingly raised the question about its impact to the conventional and Islamic equity market dynamics. In this vein, Lin \& Su (2020) highlight that analyzing the linkages between oil market uncertainty and Islamic stock markets has important implications for optimal portfolio diversification and risk reduction for Islamic investors. Mensi et al. (2020) reveal that the US conventional stock market can play only the role of hedge against oil price uncertainty while its Islamic counterpart can serve as a hedge and safe haven.

Sulemanet et al. (2021) apply the Diebold and Yilmaz methodology to investigate asymmetric volatility connectedness between the Dow Jones Islamic Market Index and the Brent crude oil, gold, and silver markets. They find on the one hand a significant volatility connectedness between the Islamic equity market and commodity markets. On the other hand, they reveal that the DJIM and Brent oil markets being the largest net contributors of spillovers. Using the same methodology, Bahloul and Khemakhem (2021) show that commodities exhibit the highest source of shocks to Islamic equity market for both full period as well as for sub-periods.

Finally, note that understanding the extent of the relationship between equity and commodity markets is a crucial task for portfolio diversification, pricing derivatives and risk-management. This issue is recently extended to Islamic finance domain. In this context, determining the type and the direction of the nexus between the markets is strategic for both international and Islamic investors. More even, it is useful to understand how this relationship varies through market conditions. Thereby, to achieve this objective, we employ in this paper the Markov switching methodology.

\section{Methodology}

In this paper, we use in a first step the vector auto-regression (VAR) approach to test the relationship between the three markets for the full period. In a second step, the Markov switching VAR (MS-VAR) approach is employed to verify whether the 
link between the considered markets varies according to volatility regimes. This approach is justified by the period under study that is characterized by the emergence of several economic and political events such as the Asian financial crisis, the dot-com bubble, the global financial crisis, the European debt crisis and the COVID19 outbreak. Such crisis affects the dynamic of commodity and Islamic markets and so their interconnection.

\subsection{VAR approach}

To examine the linear relationship between the three variables, namely the changes in the Islamic stock index, crude oil price, and gold price, we use the vector autoregressive model. Let $r_{t}=\left(r_{1 t}, r_{2 t}, \ldots, r_{k t}\right)^{T}$, a set of $k$ variables, follows a $\operatorname{VAR}(l)$ process if it satisfies:

$$
r_{t}=c+A_{1} r_{t-1}+A_{2} r_{t-2}+\cdots+A_{p} r_{t-l}+\varepsilon_{t}
$$

where $c$ is a $k$-dimensional vector of intercepts, $A$ is the $(k \times k)$ matrices of coefficients and $\varepsilon_{t}$ is a sequence of serially uncorrelated random vectors with mean zero and covariance matrix $\Sigma$.

For $k=3$, The three-equation $\operatorname{VAR}(l)$ model can be presented as follows ${ }^{5}$ :

$$
\begin{aligned}
& r_{I M}=\alpha_{0}+\sum_{i=1}^{l} \alpha_{k 1} r_{I M t-i}+\sum_{i=1}^{l} \alpha_{k 2} r_{C O t-i}+\sum_{i=1}^{l} \alpha_{k 3} r_{G D t-i}+\varepsilon_{1 t} \\
& r_{C O}=\beta_{0}+\sum_{i=1}^{l} \beta_{k 1} r_{I M t-i}+\sum_{i=1}^{l} \beta_{k 2} r_{C O t-i}+\sum_{i=1}^{l} \beta_{k 3} r_{G D t-i}+\varepsilon_{2 t} \\
& r_{G D}=\gamma_{0}+\sum_{i=1}^{l} \gamma_{k 1} r_{I M t-i}+\sum_{i=1}^{l} \gamma_{k 2} r_{C O t-i}+\sum_{i=1}^{l} \gamma_{k 3} r_{G D t-i}+\varepsilon_{3 t}
\end{aligned}
$$

where $r_{I M}, r_{C O}$ and $r_{G D}$ are the weekly returns of Islamic stock market, crude oil price and gold price, respectively. $l$ denotes the optimal lag length. As shown in the model, each variable is a linear function of its own lagged values and the lagged values of the two other variables presented in the system.

\subsection{MS-VAR approach}

As suggested by some previous studies (Chkili, 2017; Creti et al., 2013), the relationships between stock market and commodity market are not stable and dependent on the underlying market conditions. In order to take into account the regime shifts of volatility in our analysis, we apply the MS-VAR model developed by Krolzig

\footnotetext{
${ }_{5}$ In our study $\mathrm{k}=3$ refers to three markets: Islamic stock market, crude oil market, and gold market.
} 
(1997). Such model allows examining the relationship between the considered markets for normal and volatile periods. This helps Islamic investors accomplishing better hedging mechanism under both bull and bear market conditions. The MS-VAR model can be written as follows:

$$
\begin{aligned}
& r_{I M}=\alpha_{0}\left(S_{t}\right)+\sum_{i=1}^{l} \alpha_{k 1}\left(S_{t}\right) r_{I M t-i}+\sum_{i=1}^{l} \alpha_{k 2}\left(S_{t}\right) r_{C O t-i}+\sum_{i=1}^{l} \alpha_{k 3}\left(S_{t}\right) r_{G D t-i}+v\left(S_{t}\right) \varepsilon_{1 t} \\
& r_{C O}=\beta_{0}\left(S_{t}\right)+\sum_{k=1}^{l} \beta_{k 1}\left(S_{t}\right) r_{I M t-i}+\sum_{k=1}^{l} \beta_{k 2}\left(S_{t}\right) r_{C O t-i}+\sum_{k=1}^{l} \beta_{k 3}\left(S_{t}\right) r_{G D t-i}+v\left(S_{t}\right) \varepsilon_{2 t} \\
& r_{G D}=\gamma_{0}\left(S_{t}\right)+\sum_{k=1}^{l} \gamma_{k 1}\left(S_{t}\right) r_{I M t-i}+\sum_{k=1}^{l} \gamma_{k 2}\left(S_{t}\right) r_{C O t-i}+\sum_{k=1}^{l} \gamma_{k 3}\left(S_{t}\right) r_{G D t-i}+v\left(S_{t}\right) \varepsilon_{3 t}
\end{aligned}
$$

where $S_{t}$ is the unobservable discrete variable which is supposed to follow a twostate Markov switching process defined by the transition probability matrix:

$$
P=\left[\begin{array}{ll}
P_{11} & P_{21} \\
P_{12} & P_{22}
\end{array}\right]
$$

where:

$$
\left\{\begin{array}{l}
P_{11}=P\left(S_{t}=1 / S_{t-1}=1\right) \\
P_{12}=P\left(S_{t}=1 / S_{t-1}=2\right) \\
P_{21}=P\left(S_{t}=2 / S_{t-1}=1\right) \\
P_{22}=P\left(S_{t}=2 / S_{t-1}=2\right)
\end{array}\right.
$$

For all $i, j \in\{1,2\}, \sum_{j=1}^{2} P_{i j}=1$.

The average duration of regime $j$ can be calculated as follows: $D=\frac{1}{1-P_{j j}}$

\section{Data and descriptive statistics}

We use weekly closing prices for the Dow Jones Islamic World market index, gold and WTI crude oil. The sample study covers the period from January 1996 to December 2020. The data are collected from International Datastream, Federal Reserve Bank Database and EIA Database, ${ }^{6}$ respectively. The period under study covers several political and economic events such as the Asian financial crisis, the dot-com bubble, the global financial crisis, the European debt crisis and the COVID19 outbreak. Such choice enables us to examine the relationship between the variables for normal and turbulent periods. We use weekly data for two reasons. First, weekly data frequency allows avoiding any potential biases related to daily data such

\footnotetext{
${ }^{6}$ US Energy Information Administration https://www.eia.gov
} 
Table 1 Descriptive statistics and matrix of correlations

Panel A. Descriptive statistics

\begin{tabular}{llllllll}
\hline & Mean & SD & Skewness & Kurtosis & JB & LB $^{2}$ & ADF \\
\hline RDJI & 0.1314 & 2.4269 & -1.0446 & 10.595 & $3350.90^{* *}$ & $263.14^{* *}$ & $-36.756^{* *}$ \\
Roil & 0.0503 & 4.8553 & -0.5930 & 14,790 & $7582.58^{\text {***}}$ & $719.69^{* *}$ & $-27.328^{\text {** }}$ \\
Rgold & 0.1218 & 2.3152 & -0.2703 & 6.9049 & $839.205^{* *}$ & $383.41^{* *}$ & $-25.184^{* *}$ \\
\hline
\end{tabular}

Panel B. Matrix of correlations

\begin{tabular}{lllr}
\hline & RDJI & Roil & Rgold \\
\hline RDJI & 1.000 & & \\
Roil & $0.2296[0.00]$ & 1.000 & 1.000 \\
Rgold & $0.1335[0.00]$ & $0.1464[0.00]$ & \\
\hline
\end{tabular}

RDJI, Roil and Rgold are the returns of the Islamic stock market, crude oil prices and gold prices, respectively. $\mathrm{SD}$ is the standard deviation. $\mathrm{JB}$ is the Jarque-Berra test for normality, $\mathrm{LB}^{2}$ refers to the empirical statistics of Ljung-Box test for autocorrelation of squared returns series, ADF is the empirical statistics of the Augmented Dickey \& Fuller (1979) unit root test. The $p$-values are in brackets.

** indicates the rejection of null hypotheses at $1 \%$ level.

as the problem of non-synchronous trading and short-term correlations due to noise with higher frequencies. Second, some previous studies (Aloui \& Jammazi, 2008; Chkili et al., 2011; Hamilton \& Susmel, 1994) suggest that Markov switching can be a better detecting regime shifts across time using lower frequency data such as weekly data. The returns are computed by taking the natural logarithm of the ratio of two consecutive prices as follows:

$$
r_{i t}=\ln \left(\frac{P_{i t}}{P_{i t-1}}\right)
$$

where $P_{i t}$ is the price for the asset $i$ at time $t$ and $r_{i t}$ is the return of the considered asset.

Table 1 presents summary descriptive statistics and the matrix correlation between the variables. Panel A shows that the weekly average returns are positive for all the considered series. The Islamic stock market exhibits the higher average returns (13.14\%) followed by the gold market $(12.18 \%)$ while the oil market is the least profitable with an average return of $5.03 \%$. With regards to volatility, as measured by the standard deviation, the oil market appears as the most volatile while the gold market seems the stable one. The Skewness and Kurtosis normality tests show that return distributions are negatively skewed and highly leptokurtic relative to the normal distribution, respectively. The Jarque-Berra test also rejects the null hypothesis of normality as the empirical values are statistically significant at $1 \%$ level. The last column of Table 1 reports the Augmented Dickey-Fuller unit root test results for the three markets. The results show that the ADF test rejects the null hypothesis suggesting that all the return series are stationary at conventional levels. 
(a) DJIW market

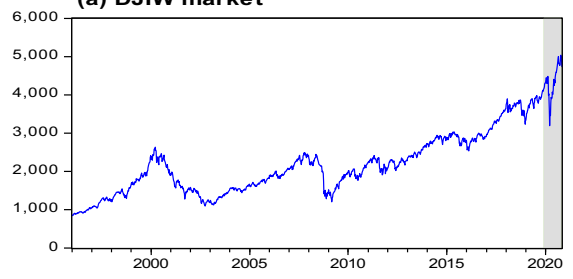

(b) Oil market

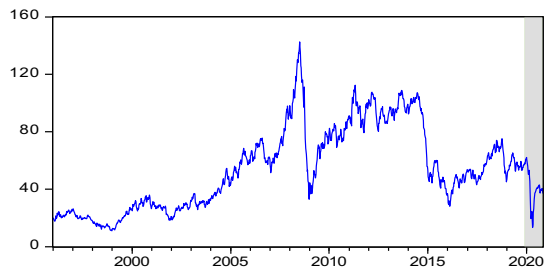

(c) Gold market

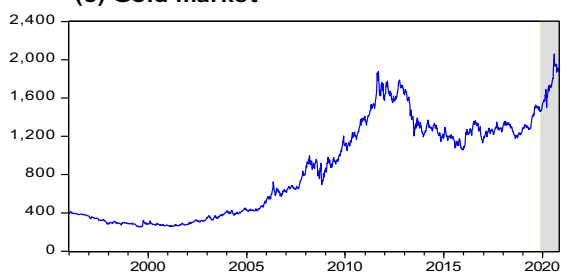

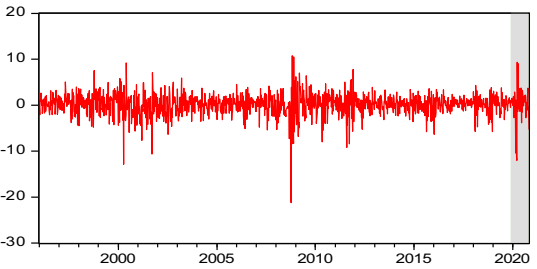
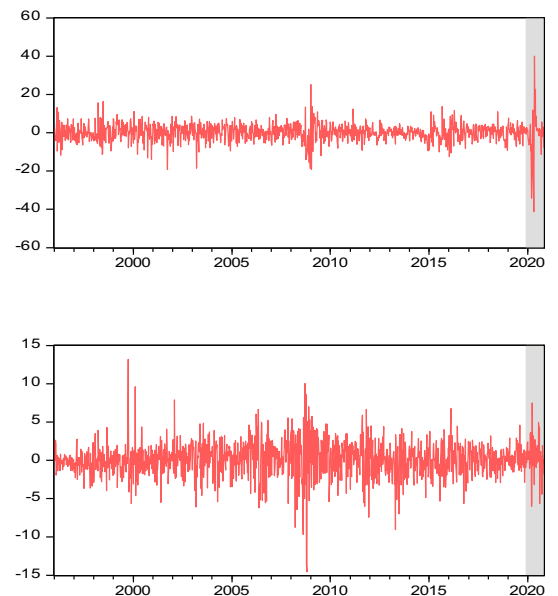

Fig. 1 Prices (left panel) and returns (right panel) for Islamic stock, oil and gold markets (The shaded area denotes the COVID-19 period). Source: International Datastream database, https://www.eia.gov and author's own calculation

Panel B presents the unconditional pairwise correlations between the three variables. We see that the average correlation is positive and significant for all cases. More precisely, this correlation varies between 0.1335 for the gold/Islamic stock return pair and 0.2296 for the crude oil/Islamic stock return pair. Note that the table presents only average values of correlation over the whole period while the relationship between the considered assets can differ significantly according to the market conditions and the regime of volatility. This requires a further analysis in Sect. 4.

Figure 1 displays the evolution of the prices and returns of the three studied markets. As shown in the left panel, the Islamic stock market and the crude oil market present similar trends. The two markets exhibit an increasing trend with some important swings during the period under investigation. Therefore, some drops can be detected namely during the global financial crisis, the European debt crisis and the coronavirus financial crisis. The gold price also experiences an increasing evolution up to 2014. Afterwards, a downward trend is observed until 2018. The right panel plots the return series for each market. From the plots, we can see the presence of volatility clustering: large (small) variations in the prices tend to be followed by large (small) variations by either sign. 
Table 2 Estimation results of VAR approach

\begin{tabular}{llll}
\hline \multicolumn{2}{c}{ RDJI } & Roil & Rgold \\
\hline \multicolumn{2}{l}{ Panel A: Estimation } & results & \\
Constant & $0.141^{* * *}(2.095)$ & $0.014(0.104)$ & $0.116^{*}(1.801)$ \\
RDJI $_{\mathrm{t}-1}$ & $-0.022(-0.776)$ & $0.212^{* * *}(3.804)$ & $0.009(0.332)$ \\
Roil $_{\mathrm{t}-1}$ & $-0.014(-0.992)$ & $0.198^{* * *}(7.102)$ & $-0.008(-0.607)$ \\
Rgold $_{\mathrm{t}-1}$ & $-0.064^{* * *}(-2.151)$ & $-0.044(-0.767)$ & $0.025(1.310)$ \\
\hline
\end{tabular}

Panel B: Residual diagnostics

$\log L \quad-6956.03$

AIC $\quad 14.9858$

SIC $\quad 15.0843$

RDJI, Roil and Rgold are the returns of the Islamic stock market, crude oil prices and gold prices, respectively. AIC is the Akaike Information criterion. SIC is the Schwartz Information criterion. Student$t$ statistics of parameters are reported in parentheses.

$* * *, * *$ and $*$ refer to significance levels at $1 \%, 5 \%$ and $10 \%$, respectively.

\section{Empirical results}

\subsection{VAR model results}

Table 2 presents the estimation results and diagnostic tests for the VAR model. We start our analysis by determining the optimal lag length of the model. According to Log-likelihood, Akaike information criterion and Schwarz information criterion the optimal lag is equal to one. ${ }^{7}$

From Table 2, we see that the estimated coefficient relating the Islamic market return and gold return is negative and statistically significant at conventional levels. This suggests that gold can serve as a strong hedge for Islamic stock market fluctuations. This result is in line with the definition of Baur \& Lucey (2010). In fact, an asset is regarded as a strong (weak) hedge if it is negatively correlated (uncorrelated) with another asset on average. Alkhazali and Zoubi (2020) provide similar results for some Islamic markets. Besides, the insignificant coefficient detected between gold and crude oil markets indicates that gold can be considered as a weak hedge against oil price movements. This result can help Islamic and International investors to opt towards an optimal portfolio hedging strategy. Risk managers should also rely on this finding in order to offer for investors effective hedging instruments.

The reported results also show that oil price returns are positively affected by the lagged values of Islamic stock returns. This result underlines the financialization process of the commodity market. In fact, the price of the crude oil is not only determined by its lagged values but also by the lagged values of Islamic equity market.

\footnotetext{
7 The optimal lag has the highest Log likelihood and the lowest Akaike and Schwarz information criteria.
} 
The hypothesis of the financialization of crude oil market has been proved by several related studies (Creti et al., 2013; Silvennoinen \& Thorp, 2013 and Gomez-Gonzalez et al, 2021). This hypothesis predicts that changes of stock market returns can affect crude oil prices and consequently the behavior of this market largely depends on the dynamics of financial markets.

Shahzad et al. (2018) examine the risk spillover between oil price volatility and the Dow Jones Islamic Market (DJIM) as a benchmark index for Islamic stock markets. Using the copula approach, their results find evidence of positive and extreme lower tail dependence between the crude oil prices and the Islamic stock markets. According to the authors, the two markets co-move in the same direction and so the drop of oil price leads to a low Islamic stock market performance.

Arfaoui and Raggad (2021) and Khan et al. (2015) discover a significant dynamic links between Islamic equities and commodity prices namely during major events confirming the financialization process of commodity markets. In addition, the authors support the speculation phenomenon for these markets except for gold considering its safe haven propriety.

\subsection{Regime shifts in the relationship between commodity and Islamic stock markets}

Table 3 reports the estimation results of the MS-VAR approach. We begin with testing whether regime shifts exist in the relationship between the three markets. Practically, we apply the likelihood ratio (LR) test calculated as follow ${ }^{8}$ :

$$
L R=2 \times\left|\log L_{M S-V A R}-\log L_{V A R}\right|
$$

where $\log L_{M S-V A R}$ and $\log L_{V A R}$ are the $\log$ likelihood for the MS-VAR and VAR models, respectively. The LR test statistic reported in panel A is significant at the $1 \%$ level. We can thus reject the null hypothesis of no regime switching in the link between commodity and Islamic stock markets. This result implies that the MS-VAR process is suitable for testing the dynamic linkage between the considered markets under condition of regime changes.

From the estimation results, we can identify two types of regime: a low volatility regime (regime 1) and a high volatility regime (regime 2 ). As shown in the Table 3 , the estimated volatility for regime 1 is 1.241 for Islamic market, 2.428 for oil and 1.606 for gold. While in regime 2, the extent of volatility is more important for all considered markets and varies between 2.023 for gold and 4.117 for crude oil. Furthermore, the probability of staying in regime of low volatility, in other words the probability that a week of low volatility will be pursued of a week of low volatility is equal to 0.981 . The probability of staying in regime of high volatility is less important and is around 0.971 . The average duration of the low volatility regime is 52.63 weeks (13.16 months) while the high volatility regime is less persistent and lasts on average 37.04 weeks (8.62 months).

\footnotetext{
${ }^{8}$ For more details, see Garcia (1998) and Garcia \& Perron (1996).
} 
Table 3 Estimation results of MS-VAR approach

\begin{tabular}{|c|c|c|c|c|}
\hline & & RDJI & Roil & Rgold \\
\hline \multicolumn{5}{|c|}{ Panel A: Regime switching tests } \\
\hline LR test & $179.48[0.000]$ & & & \\
\hline $\log L$ & -6866.29 & & & \\
\hline \multicolumn{5}{|c|}{ Panel B: Estimation results } \\
\hline constant & & $0.351^{* * *}(6.611)$ & $0.329^{* *}(2.535)$ & $0.086(1.461)$ \\
\hline \multirow[t]{2}{*}{$\mathrm{RDJI}_{\mathrm{t}-1}$} & regime 1 & $-0.127^{* *}(-2.280)$ & $0.301^{*}(1.728)$ & $-0.085^{*}(-2.074)$ \\
\hline & regime 2 & $-0.014(0.309)$ & $0.185^{* *}(2.121)$ & $-0.441^{* *}(-2.511)$ \\
\hline \multirow[t]{2}{*}{ Roil $_{t-1}$} & regime 1 & $0.018(0.537)$ & $0.197^{* * *}(3.179)$ & $-0.006(-0.394$ \\
\hline & regime 2 & $0.183^{*}(2.087)$ & $0.158^{* * *}(3.511)$ & $-0.008(-0.194)$ \\
\hline \multirow[t]{2}{*}{ Rgold $_{t-1}$} & regime 1 & $-0.014(-0.112)$ & $-0.098(-1.308)$ & $0.058(1.149)$ \\
\hline & regime 2 & $-0.117^{*}(-1.860)$ & $0.058(0.523)$ & $-0.074(-1.068)$ \\
\hline \multirow[t]{2}{*}{ std. dev. } & regime 1 & 1.241 & 2.428 & 1.606 \\
\hline & regime 2 & 2.164 & 4.117 & 2.023 \\
\hline
\end{tabular}

Panel C: Regime characteristics

\begin{tabular}{llll}
\hline Duration & regime 1 & 52.63 & \\
& regime 2 & 34.48 & \\
\hline Probability & $P_{11}$ & 0.981 & 0.028 \\
& $P_{22}$ & 0.209 & 0.971 \\
\end{tabular}

Correlation coefficient

\begin{tabular}{|c|c|c|c|c|}
\hline \multirow[t]{2}{*}{ RDJI } & \multicolumn{3}{|l|}{ regime 1} & 0.384 \\
\hline & \multicolumn{3}{|l|}{ regime 2} & 0.105 \\
\hline \multirow[t]{2}{*}{ Roil } & regime 1 & 0.143 & & \\
\hline & regime 2 & 0.272 & & \\
\hline \multirow[t]{2}{*}{ Rgold } & regime 1 & & 0.379 & \\
\hline & regime 2 & & 0.106 & \\
\hline
\end{tabular}

Panel D: Residual diagnostics

$\log L \quad-6866.29$

$\begin{array}{ll}\text { AIC } & 14.9544 \\ \text { SIC } & 15.0538\end{array}$


Table 3 (continued)

RDJI, Roil and Rgold are the returns of the Islamic stock market, crude oil prices and gold prices, respectively. AIC is the Akaike Information criterion. SIC is the Schwartz Information criterion. Student- $t$ statistics of parameters are reported in parentheses. LR statistics is test calculated as $2 \times\left|\log L_{M S-V A R}-\log L_{V A R}\right| \cdot p$-values are in brackets.

$* * *, * *$ and $*$ refer to significance levels at $1 \%, 5 \%$ and $10 \%$, respectively.

Figure 2 plots the evolution of the smoothed probabilities of regime 1 (upper panel) and regime 2 (lower panel). We can see that the high volatility regime coincides mostly with the periods of the major political and economic events that occurred during the period under examination such as the Asian financial crisis, the dot-com bubble, the Global financial crisis, the European debt crisis and the COVID-19 outbreak.

The estimation results displayed in Table 3 show that the estimated coefficients connecting gold to the oil and Islamic stock market returns are negative and not significant for the normal period that corresponds to low volatility regime. This confirms the role of gold as a hedge for both oil and Islamic markets. Seetharam and Bodington (2015) point out that hedges are useful instruments for portfolio risk management and gold has been classified as hedges against many economic and financial variables in addition to its value as a financial asset.

Turning to regime 2, empirical findings display positive and significant link of oil to Islamic stocks. More precisely, changes in oil prices are predicted based on previous oil price changes and Islamic stock index innovations during turbulent periods. This interdependence confirms the financialization mechanism of crude oil market. This result is in line with those of Creti et al. (2013). According to the authors, a
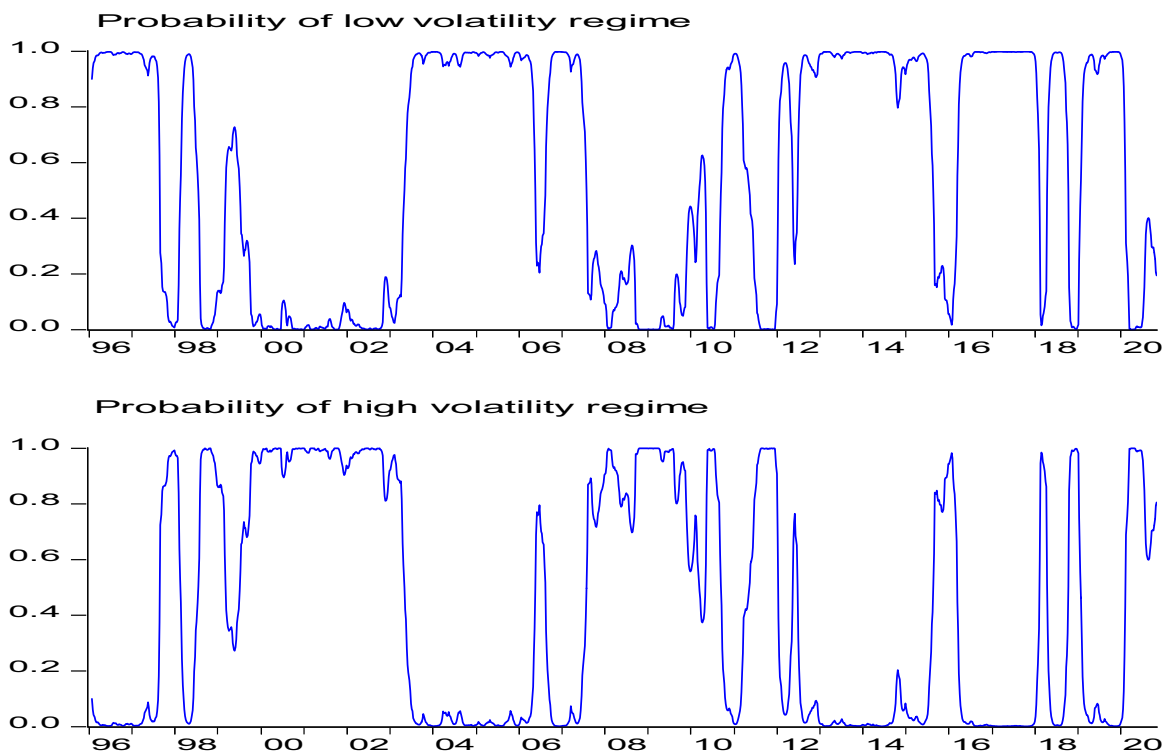

Fig. 2 Smoothed probability for low and high volatility regimes 
high correlation is observed between the two markets during financial turbulences which reflecting the phenomenon of financialization of oil market. Shahzad et al. (2018) find similar results for Islamic market. They reveal an extreme positive lower dependence between the oil and the Islamic indexes. This interdependence reduces the diversification opportunities for international investors during turmoil periods.

The findings also exhibit negative and significant links between Islamic returns and gold price changes during the high volatility regime. This suggests that gold serves as a strong safe haven during turbulent Islamic stock market conditions. Chkili (2017) finds quite similar results for some Islamic markets. He concludes that gold is an effective safe haven against extreme Islamic stock market movements. According to the author, this can be explained by the fact that the price of gold maintained its increasing trend during the period of the major crises. More precisely, the demand for gold increases given that investors sell assets associated with high risk and purchase haven assets during extreme political and financial turmoil. This movement is consistent with the flight to quality phenomenon (Hammoudeh et al., 2010; Klein, 2018). Nagayev et al. (2016) reveal that correlation between gold and Islamic market is around $0 \%$ during turbulent periods. They explain the weakening of correlation by the divergence between equity and precious metal prices since the gold price increases during financial market turmoil as opposed to equity prices. The authors conclude that gold continues to play its role as a safe haven during turbulent periods.

Finally, the insignificant coefficient linking oil price and gold lagged values highlights that gold can act as a weak safe haven against extreme down movements in oil market. This result is in line with the findings of Reboredo (2013b). Using a copula approach, his result points out that gold exhibits the propriety of a safe haven asset in falling crude oil prices.

Panel $\mathrm{C}$ reports the correlation coefficients between the three assets for the low and high volatility regimes. It can be observed that the values of the coefficients for the couple gold/oil and the couple gold/Islamic stock returns are low during the high volatility regime confirming the role of gold as a safe haven for extreme stock and oil markets movements. Moreover, the correlation between the oil and Islamic stock returns is high during turbulent state suggesting the strong connection between the two markets namely during crisis periods.

On the whole, our findings show some resemblance between Islamic and conventional stock markets concerning their relationship with commodity prices. As shown in Fig. 3, the links between commodity and Islamic stock market varies across the regimes. The major conclusion provided is the financialization process of the crude oil markets with the reference to the links between oil and Islamic stock markets. This result has several implications for Islamic investors who want to share their wealth among several assets in order to reduce the portfolio risk. In addition, the negative link between gold prices and Islamic markets offer a better diversification opportunity given that gold can act as a strong hedge and safe haven against Islamic stock market volatility. 
Regime 1: low volatility

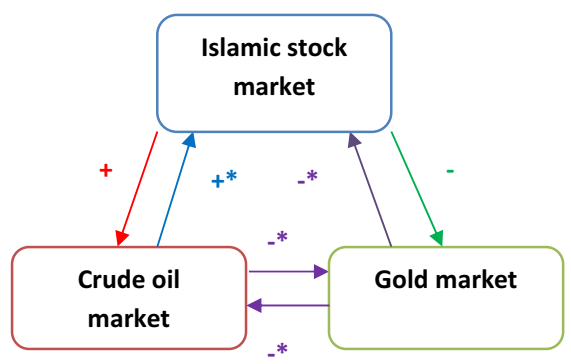

Regime 2: high volatility

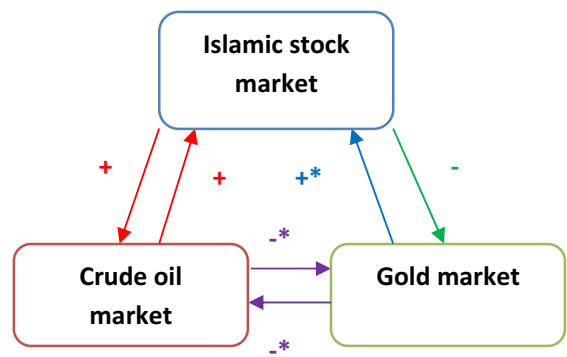

Fig. 3 Summary of the relationship between Islamic stock, oil and gold for low and high volatility regimes. Four types of link are identified: Positive and no significant $\left(+^{*}\right)$. Negative and no significant $(-*)$. Positive et significant $(+)$. Negative and significant $(-)$. Source: author's own calculation

\section{Conclusion}

The links between the conventional stock markets and commodity markets are widely investigated in the literature. Recently, the topic is gradually extended to the Islamic finance area. In fact, analyzing the connectedness between financial and commodity markets has important practical implications in terms of portfolio composition, risk assessment and hedging effectiveness. However, the consideration of market conditions is crucial in achieving the effective portfolio diversification and better hedging benefits.

In this paper we investigate the relationship between Islamic stock market and two major commodities namely gold and crude oil for the period ranging from January 1996 to December 2020. We first use the VAR approach to detect the type of links between the three variables for the whole period. The empirical findings show a positive relationship between oil and Islamic stock markets confirming the financialization process of the crude oil market. In addition, the negative relationship uncovered between Islamic equity market and gold highlights the role of gold as a strong hedge for Islamic market volatility.

Secondly, by considering the Markov switching approach, we find that the relationship between the variables varies across volatility regimes and depending on the market conditions. For the low volatility regime, results confirm the role of gold as a hedge for Islamic market movements. As regards the high volatility regime, the empirical evidence reveals a negative and significant connection between Islamic index and gold price changes. This finding provides evidence that gold can be regarded as safe haven against extreme Islamic stock market conditions.

These findings have several implications for portfolio managers and Islamic investors when they decide to share their wealth between different assets. Such decision requires a better understanding of the relationship between markets in order to opt for the most beneficial portfolio diversification design and to choose the optimal hedging strategy. 
Funding This work was sponsored by the Economic Research Forum (ERF) and has benefited from both financial and intellectual support. The contents and recommendations do not necessarily reflect ERF's views.

\section{Declarations}

Conflict of interest The author declares that there is no conflict of interest.

Ethical approval No ethic approval was required for this study.

Informed consent No Informed consent was required for this study.

\section{References}

Adekoya, O. B., Oliyide, J., \& Oduyemi, G. (2020). How COVID-19 upturns the hedging potentials of gold against oil and stock markets risks: Nonlinear evidences through threshold regression and Markov regime switching models. Resources Policy, 70, 101926.

Alkhazali, O. M., \& Zoubi, T. A. (2020). Gold and portfolio diversification: A stochastic dominance analysis of the Dow Jones Islamic indices. Pacific-Basin Finance Journal, 60, 101264.

Aloui, C., \& Jammazi, R. (2008). The effects of crude oil shocks on stock market shifts behavior: A regime switching approach. Energy Economics, 31, 789-799.

Arfaoui, M., \& Raggad, B. (2021). Do Dow Jones Islamic equity indices undergo speculative pressure? New insights from a nonlinear and asymmetric analysis. International Journal of Finance and Economics. https://doi.org/10.1002/ijfe.2495 In press.

Bahloul, S., \& Khemakhem, I. (2021). Dynamic return and volatility connectedness between commodities and Islamic stock market indices. Resources Policy, 71, 101993.

Baur, D. G., \& McDernott, T. K. (2010). Is gold a safe haven? International evidence. Journal of Banking and Finance, 34, 1886-1898.

Boubaker, H., \& Raza, S. A. (2017). A wavelet analysis of mean and volatility spillovers between oil and BRICS stock markets. Energy Economics, 64, 105-117.

Chebbi, T., \& Derbali, A. (2015). The dynamic correlation between energy commodities and Islamic stock market: Analysis and forecasting. International Journal of Trade and Global Markets, 8, $112-126$.

Chebbi, T., \& Derbali, A. (2016). A dynamic conditional correlation between commodities and the Islamic stock market. Journal of Energy Markets, 9, 65-90.

Chkili, W. (2015). Gold-oil prices co-movements and portfolio diversification implications. Economics Bulletin, 35, 2832-2845.

Chkili, W. (2016). Dynamic correlations and hedging effectiveness between gold and stock markets: Evidence for BRICS countries. Research in International Business and Finance, 38, 22-34.

Chkili, W. (2017). Is gold a hedge or safe haven for Islamic stock market movements? A Markov switching approach. Journal of Multinational Financial Management, 42-43, 152-163.

Chkili, W., Aloui, C., Masood, O., \& Fry, J. (2011). Stock market volatility and exchange rates in emerging countries: A Markov-state switching approach. Emerging Markets Review, 12, 272-292.

Chkili, W., Aloui, C., \& Nguyen, D. K. (2014). Instabilities in the relationships and hedging strategies between crude oil and US stock markets: Do long memory and asymmetry matter? Journal of International Financial Markets, Institutions and Money, 33, 354-366.

Ciner, C., Gurdgiev, C., \& Lucey, B. M. (2013). Hedges and safe havens: An examination of stocks, bonds, gold, oil and exchanges rates. International Review of Financial Analysis, 29, 202-211.

Coudert, V., \& Raymond-Feingold, H. (2011). Gold and financial assets: Are there any safe havens in bear markets? Economics Bulletin, 31, 1613-1622.

Creti, A., Joets, M., \& Mignon, V. (2013). On the links between stock and commodity markets' volatility. Energy Economics, 37, 16-28.

Dicky, D. A., \& Fuller, W. A. (1979). Distribution of the estimators for autoregressive time series with a unit root. Journal of the American Statistical Association, 74, 427-431. 
Filis, G., Degiannakis, S., \& Floros, C. (2011). Dynamic correlation between stock market and oil prices: The case of oil-importing and oil-exporting countries. International Review of Financial Analysis, 20, 152-164.

Garcia, R. (1998). Asymptotic null distribution of the likelihood ratio test in Markov switching models. International Economic Review, 39, 763-788.

Garcia, R., \& Perron, P. (1996). An analysis of the real interest rate under regime shifts. The Review of Economics and Statistics, 78, 111-125.

Gomez-Gonzalez, J. E., Hirs-Garzon, J., \& Sanín-Restrepo, S. (2021). Dynamic relations between oil and stock markets: Volatility spillovers, networks and causality. International Economics, 135, 37-50.

Hamilton, J. D., \& Susmel, R. (1994). Autoregressive conditional hetroscedasticity and changes in regime. Journal of Econometrics, 70, 127-157.

Hammoudeh, S., Mensi, W., Reboredo, J. C., \& Nguyen, D. K. (2014). Dynamic dependence of the global Islamic equity index with global conventional equity market indices and risk factors. PacificBasin Finance Journal, 30, 189-206.

Hammoudeh, S. M., Yuan, Y., McAleer, M., \& Thompson, M. A. (2010). Precious metals-exchange rate volatility transmissions and hedging strategies. International Review of Economics and Finance, 19, 633-647.

IFSI (2018). The IFSB Islamic Financial Services Industry Stability Report 2018. Available at: https:// www.ifsb.org.

Izadi, S., \& Hassan, M. K. (2018). Portfolio and hedging effectiveness of financial assets of the G7 countries. Eurasian Economic Review, 8, 183-213.

Khan, A. P., Kabir, S. H., Bashar, O., \& Masih, M. (2015). Time varying correlation between Islamic equity and commodity returns: Implications for portfolio diversification. The Journal of Developing Areas, 49, 115-128.

Klein, T. (2018). Dynamic correlation of precious metals and flight-to-quality in developed markets. Finance Research Letters, 23, 283-290.

Kolodziej, M., Kaufmann, R. K., Kulatilaka, N., Bicchetti, D., \& Maystre, N. (2014). Crude oil: commodity or financial asset? Energy Economics, 46, 216-223.

Krolzig, H. M. (1997). Markov switching autoregressive: Modeling statistical inference and application to business cycles analysis. Berlin, Heidelberg: Springer. https://doi.org/10.1007/978-3-642-51684-9

Lang, K., \& Auer, B. R. (2019). The economic and financial properties of crude oil: A review. North American Journal of Economics and Finance, 52, 100914.

Lin, B., \& Su, T. (2020). The linkages between oil market uncertainty and Islamic stock markets: Evidence from quantile-on-quantile approach. Energy Economics, 88, 1-10.

Maghyereh, A. I., Abdoh, H., \& Awartani, B. (2019). Connectedness and hedging between gold and Islamic securities: A new evidence from time-frequency domain approaches. Pacific Basin Finance Journal, 54, 13-28.

Mensi, W., Selmi, R., \& Al-Yahyaee, K. H. (2020). Switching dependence and systemic risk between crude oil and U.S. Islamic and conventional equity markets: A new evidence. Resources Policy, 88 , 101861.

Metadjer, W., \& Boulila, H. (2018). Causal relationship between Islamic bonds, oil price and precious metals: Evidence from Asia Pacific. Journal of Islamic Economics, 10, 285-298.

Mokni, K., \& Youssef, M. (2019). Measuring persistence of dependence between crude oil prices and GCC stock markets: A copula approach. Quarterly Review of Economics and Finance, 72, 14-33.

Naeem, M. A., Qureshi, F., Arif, M., \& Balli, F. (2021). Asymmetric relationship between gold and Islamic stocks in bearish, normal and bullish market conditions. Resources Policy, 72, 102067.

Nagayev, R., Disli, M., Inghelbrecht, K., \& Ng, A. (2016). On the dynamic links between commodities and Islamic equity. Energy Economics, 58, 125-140.

Naifer, N. (2018). Exploring the dynamic links between GCC sukuk and commodity market volatility. International Journal of Financial Studies, 6, 1-18.

Olson, E., Vivian, A. J., \& Wohar, M. E. (2014). The relationship between energy and equity markets: Evidence from volatility impulse response functions. Energy Economics, 43, 297-305.

Reboredo, J. C. (2013a). Is gold a safe haven or a hedge for the US dollar? Implications for risk management. Journal of Banking and Finance, 37, 2665-2676.

Reboredo, J. C. (2013b). Is gold a hedge or safe haven against oil price movements? Resources Policy, 38, $130-137$.

Saadaoui, A., Saidi, K., \& Kriaa, M. (2020). Transmission of shocks between bond and oil markets. Managerial Finance, 46, 1231-1246. 
Sakaki, H. (2019). Oil price shocks and the equity market: Evidence for the S\&P 500 sectoral indices. Research in International Business and Finance, 49, 137-155.

Sakti, M. R. P., Masih, M., Saiti, B., \& Tareq, M. A. (2018). Unveiling the diversification benefits of Islamic equities and commodities Evidence from multivariate-GARCH and continuous wavelet analysis. Managerial Finance, 44, 830-850.

Salisu, A., \& Adediran, I. (2020). Gold as a hedge against oil shocks: Evidence from new datasets for oil shocks. Resources Policy, 66, 101606.

Salisu, A., Vo, X. V., \& Lawal, A. (2020). Hedging oil price risk with gold during COVID-19 pandemic. Resources Policy, 70, 101897.

Seetharam, Y., \& Bodington, L. (2015). Gold in the South Africa market: A safe haven or hedge? Applied Economic Quarterly, 61, 331-352.

Shahzad, S. J. H., Bouri, E., Roubaud, D., \& Kristoufek, L. (2020). Safe haven, hedge and diversification for G7 stock markets: Gold versus Bitcoin. Economic Modelling, 87, 212-224.

Shahzad, S. J. H., Mensi, W., Hammoudeh, S., Rehman, M. U., \& Al-Yahyaee, K. H. (2018). Extreme dependence and risk spillovers between oil and Islamic stock markets. Emerging Markets Review, 34, 42-63.

Silvennoinen, A., \& Thorp, S. (2013). Financialization, crisis and commodity correlation dynamics. Journal of International Financial Markets, Institutions and Money, 24, 42-65.

Suleman, M. T., Mclver, R., \& Kang, S. H. (2021). Asymmetric volatility connectedness between Islamic stock and commodity markets. Global Finance Journal, 49, 100653.

Tiwari, A. K., \& Sahadudheen, I. (2015). Understanding the nexus between oil and gold. Resources Policy, 46, 85-91.

Tuna, G. (2019). Interaction between precious metals price and Islamic stock markets. International Journal of Islamic and Middle Eastern Finance and Management, 12, 96-114.

Uddin, G. S., Hernandez, J. A., Shahzad, S. J., \& Kang, S. H. (2020). Characteristics of spillovers between the US stock market and precious metals and oil. Resources Policy, 66, 101201.

Vardar, G., Coskun, Y., \& Yelkenci, T. (2018). Shock transmission and volatility spillover in stock and commodity markets: Evidence from advanced and emerging markets. Eurasian Economic Review, 8, 231-288.

Wen, X., \& Cheng, H. (2018). Which is the safe haven for emerging stock markets, gold or the US dollar? Emerging Markets Review, 35, 69-90.

Zhang, Y. J., Chevallier, J., \& Guesmi, K. (2017). De-financialization of commodities? Evidence from stock, crude oil and natural gas markets. Energy Economics, 68, 228-239.

Publisher's Note Springer Nature remains neutral with regard to jurisdictional claims in published maps and institutional affiliations. 